\title{
Analisis Pajak Bumi dan Bangunan Dalam Persepsi Masyarakat di Kecamatan Tilamuta Kabupaten Boalemo
}

\author{
Balada RAF.S.Sos.,M.Si \\ baladaraf67@gmail.com \\ Universitas Ichsan Gorontalo
}

\begin{abstract}
Land and buiding tax is the main source ini regional development. This study raised hoh people's interest in ttheir obligation to the state. As for objectives to be achieved in this studi is to desceribbe the public perception of the obligation to pay taxes in subdistrict of Tilamuta and to find out what factors influence the formation of community persception. This type of research is quantitative descriptive survey research that is taking sampels from a population and using a questionnaire. Aims to explain condition, summarize the various conditions and situation and variables that arise in the community. Based on what happened thes raised to the surface of the character or description of condition of situation and its variables. The population of this research is community of Tilamuta sub-district whose sampels were taken from all villages using the frank linch formula with total of 100 sampel. The results of research data processing show that most respondents know about land and building taxes. The awareness of the community in paying Tilamuta land and building taxes is quite high, this cann be seen from the level of public education that began to improve. The socialization given by the regional government was also quite good but not yet maximized.
\end{abstract}

Keywords: Land and Building Tax, Community perception 


\section{Pendahuluan}

Setiap wilayah suatu Negara (daerah) memiliki perencanaan aktivitas pembangunan yang merupakan bagian dari kegiatan pemerintah yang harus kontinyu dan konprehensif serta terintegrasi dengan tujuan untuk mewujudkan suatu masyarakat adil dan makmur, merata materil dan spirituil berdasarkan konstitusi sebagaimana yang tertuang di dalam Pancasila dan UUD 1945. Sehingga dengan demikian Pembangunan idealnya dilaksanakan merata di seluruh tanah air dan benarbenar dapat dirasakan oleh seluruh rakyat sehingga apa yang menjadi tujuan pembangunan nasional dapat tercapai.

Prinsip otonomi mewajibkan daerah yang bersangkutan untuk mengatur dan mengurus rumah tangganya sendiri baik untuk urusan rutin maupun tugas-tugas pembangunan daerah. Otonomi daerah tentunya memerlukan dana yang seharusnya disediakan oleh daerah sendiri dengan menggali potensi ekonomi daerah sehingga mampu meningkatan keuangan daerah yang merupakan prasyarat penting baik tegaknya otonomi daerah selain persyaratan sumber daya manusia dan sumber fasilitas menyangkut sarana dan prasarana. Pendapatan Asli Daerah
(PAD) merupakan salah satu sumber pembiayaan penyelenggaraan pemerintah serta pembangunan daerah.

Disamping sebagai salah satu sumber pembiayaan penyelenggaraan pemerintahan daerah, PAD berfungsi juga sebagai kriteria untuk mengukur ketergantungan suatu pemerintah daerah kepada pemerintah pusat. Sehubungan hal ini upaya meningkatkan penerimaan negara melalui sektor perpajakan dimaksud telah secara tegas diamanatkan dalam GBHN 1993. Kesadaran masyarakat membayar pajak secara jujur dan bertanggung jawab terus ditingkatkan melalui motivasi, penerangan, penyuluhan, pendidikan sejak dini, serta Langkah keteladanan. Peningkatan kesadaran masyarakat untuk membayar pajak sebagai warga negara perlu di imbangi dengan peningkatan pelayanan.

Pembangunan memang tidak mengenal selesai dalam kehidupan manusia. Karena aktivitas ini merupakan suatu proses yang berlangsung secara berkesinambungan dan membutuhkan supply energy besar salah satunya bersumber dari pajak. Urgensitas pajak terutama untuk pembiayaan pembangunan, hal ini tidak lain karena aktivitas warga/masyarakat memerlukan 
sarana dan prasanana, baik infrastruktur ekonomi pendidikan dan kesehatan dan lain sebagainya, termasuk rasa aman dan nyaman. Keberadaan infrastruktur public menjadi bagian dari tanggung jawab pemerintah yang dipenuhi melalui pajak.

\section{Demikian halnya di Kecamatan} Tilamuta, penyediaan kebutuhan infrastruktur public seperti Jembatan, jalan dan taman yang ada di Kecamatan Tilamuta tersebut memerlukan biaya yang bersumber dari masyarakat yang memanfaatkan dalam bentuk pajak. Untuk mewujudkan keberhasilan pembangunan, inisiatif dan kreativitas masyarakat yang lahir dari kesadaran dan tanggung jawab sebagai manusia yang hidup bermasyarakat dan diharapkan tumbuh dan berkembang sebagai suatu partisipasi inklud dalam hal pajak. Pajak adalah pungutan wajib dari rakyat untuk Negara penggunaannya untuk membiayai belanja pemerintah pusat dan daerah demi kesejahteraan rakyat.

Uang pajak digunakan untuk kepentingan umum yang merupakan salah satu sumber dana pemerintah untuk mendanai pembangunan fasilitan umum. Pemerintah menempatkan sektor perpajakan sebagai salah satu wujud untuk meningkatkan daya dukung rakyat dalam pembangunan. Karena betapapun besarnya peranan pemerintah, disiplin serta dedikasi aparaturnya dalam pengelolahan pembangunan, partisipasi masyarakat sangatlah diperlukan untuk menjamin berhasilnya pembangunan tersebut.

Partisipasi masyarakat disini adalah seperti yang diungkapkan oleh Suryono (2010:124) Partisipasi merupakan ikut sertanya masyarakat dalam pembangunan, ikut dalam kegiatan pembangunan dan ikut memanfaatkan dan menikmati hasil hasil pembangunan. Pajak Bumi dan Bangunan adalah pajak yang dipungut atas tanah dan bangunan karena adanya keuntungan dan/atau kedudukan sosial ekonomi yang lebih baik bagi orang atau badan yang mempunyai suatu hak atasnya atau memperoleh manfaat dari padanya.

Eksistensi pajak dalam Negara sangat vital dalam menjalankan roda pemerintahan untuk menjalankan fungsi fungsi pelayanan, perlindungan dan pembangunan. Demikian pentingnya, maka pajak diatur dalam konstitusi Negara UUD 1945 bahwa segala pajak untuk keperlua Negara berdasarkan Undang Undang. Menurut UU No. 12 Tahun 1985 sebagaimana telah diubah 
terakhir dengan UU No. 12 Tahun 1994

Tentang Pajak Bumi dan Bangunan, PBB adalah pajak yang bersifat kebendaan dalam arti besarnya pajak terutang ditentukan oleh keadaan objek yaitu bumi/tanah dan atau bangunan. Objek PBB adalah Bumi dan atau Bangunan. Bumi yaitu permukaan bumi dan tubuh bumi yang ada dipedalaman.

Bangunan adalah konstruksi teknik yang ditanam atau dilekatkan secara tetap pada tanah dan/atau perairan Indonesia. Sebagaimana jenis pajak yang lain, PBB akan selalu berkaitan dengan fungsi budgeter dan regulasi. Masalah penting yang harus selalu diperhatikan dalam pengenaan pajak adalah distribusi beban pajak pada masyarakat. Salah satu syarat dan penetapan pajak adalah harus memenuhi prinsip keadilan. Ada dua tolok ukur yang dapat digunakan untuk melihat adil tidaknya distribusi beban pajak. Pertama adalah prinsip kemampuan untuk membayar dan kedua adalah prinsip manfaat.

Kemampuan untuk membayar pajak dapat dilihat dari ketiga aspek, yaitu tingkat pendapatan, jumlah kekayaan dan konsumsi seseorang. Di mana semakin tinggi kemakmurannya seseorang maka semakin tinggi pula kemampuan orang tersebut untuk membayar pajak. Oleh karena itu akan lebih adil apabila orang tersebut dikenakan pajak relatif tinggi. Pemerintah sudah melakukan pendataan dan pengolahan data terhadap objek yang dikenakan pajak. Masyarakat yang sudah menjadi wajib pajak, banyak yang tidak patuh dan tidak ikut berpartisipasi terhadap pembayaran PBB. Sampai sekarang kesadaran masyarakat membayar pajak masih belum mencapai tingkat sebagaimana yang diharapkan.

Umumnya masyarakat masih sinis dan kurang percaya terhadap keberadaan pajak karena masih merasa sama dengan upeti, memberatkan, pembayarannya sering mengalami kesulitan, ketidak mengertian masyarakat apa dan bagaimana pajak dan ribet menghitung dan melaporkannya. Pemungutan pajak memang bukan suatu pekerjaan yang mudah, disamping peran serta yang aktif dan petugas perpajakan, juga dituntut kemauan dari para wajib pajak itu sendiri. Wajib pajak PBB adalah orang pribadi atau badan yang memiliki hak dan/atau memperoleh manfaat atas tanah dan/atau memiliki, menguasai, dan/atau memperoleh manfaat atas bangunan. Wajib pajak memiliki 
kewajiban membayar PBB yang terutang setiap tahunnya. PBB harus dilunasi paling lambat 6 (enam) bulan sejak tanggal diterimanya SPPT oleh wajib pajak.

Kesadaran wajib pajak dalam membayar kewajiban perpajakannya merupakan hal penting dalam penarikan pajak tersebut, suatu hal yang paling menentukan dalam keberhasilan pemungutan pajak adalah kemauan wajib pajak untuk melakukan kewajiban tersebut. Meskipun pemerintah setempat sudah membuat sanksi terhadap wajib pajak yang tidak patuh, sanksi yang diberikan oleh pemerintah yakni berupa denda. Tapi hal ini juga kurang berhasil untuk membuat masyarakat itu menjadi sadar pajak.

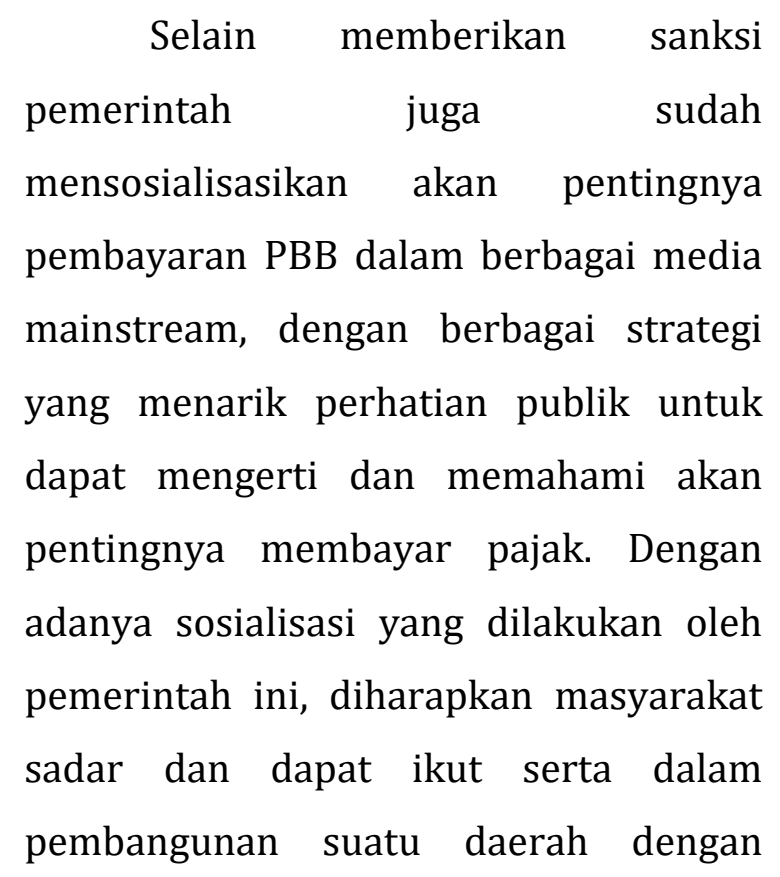

berpartisipasi membayar pajak
khususnya PBB.

Pemerintah Kabupaten Boalemo dengan potensi sumberdaya struktur dan infrastruktur terus mengoptimalkan pemungutan PBB dengan beberapa upaya yaitu dengan melalui Dinas Pendapatan Daerah (Dispenda) memaksimalkan realisasi Pajak Bumi dan Bangunan Perkotaan dan Pedesaan di setiap masing-masing kecamatan. Selain itu, pemerintah kabupaten Boalemo telah melakukan upaya - upaya antara lain, menyiapkan tempat pelayanan PBB baik ditingkat Kabupaten maupun ditingkat kecamatan, melakukan koordinasi dengan KPP Pratama terkait dengan aplikasi data PBB beserta pendampingannya dan melakukan koordinasi dengan Bank Sulut-Go terkait pembukaan penerimaan dan tempat pembayaran PBB di masing - masing kecamatan. Berdasarkan uraian tersebut, peneliti mengambil judul " Analisis Pajak Bumi dan Bangunan Dalam Persepsi Masyarakat di Kecamatan Tilamuta Kabupaten Boalemo di Kecamatan Tilamuta Kabupaten Boalemo".

\section{KAJIAN LITERATUR}

Penelitian pertama berjudul Persepsi Wajib Pajak Terhadap Pajak 
Bumi dan Bangunan Daiam Rangka Meningkatkan Penerimaan PBB di Kecamatan Ilir Barat I Palembang dilakukan oleh Merry Eryanti (2010). Perumusan masalah dalam penelitian sebelumnya adalah bagaimana persepsi wajib pajak dalam membayar Pajak Bumi dan Bangunan di Kecamatan Ilir Barat 1 Palembang. Adapun tujuan penelitiannya adalah untuk mengetahui persepsi wajib pajak dalam membayar Pajak Bumi dan Bangunan di Kecamatan Ilir Barat I Palembang. Data yang digunakan adalah data primer dan teknik pengumpulan data berupa wawancara dan dokumentasi.

Penelitian kedua berjudul Evaluasi Peiaksanaan Proses Penagihan Aktif terhadap Tunggakan PBB dan BPHTB pada Kantor Pelayanan Pajak Seberang Ulu oieh M. Amin (2006). Perumusan masalah dalam penelitian tersebut bagaimana peiaksanaan penagihan aktif di Kantor Pelayanan Pajak Palembang Seberang Ulu dan kontribusinya terhadap penerimaan. Adapun tujuannya adalah untuk mengetahui peiaksanaan penagihan aktif terhadap tunggakan PBB dan BPHTB di Kantor Pelayanan Pajak Palembang Seberang Ulu dan Kontribusinya terhadap penerimaan.
Penelitian ketiga berjudul Analisis Pengaruh Faktor Tingkat Pendapatan dan lingkat Pendidikan Wajib Pajak Terhadap Perilaku Menunggak Pembayaran Pajak Bumi dan Bangunan Pada Kecamatan Ilir Timur II Kota Palembang oleh Riantri Hastuti (2005). Perumusan masalah dalam penelitian tersebut adalah apakah tingkat pendapatan dan tingkat pendidikan Wajib Pajak mempengaruhi terhadap perilaku menunggak pembayaran Pajak Bumi dan Bangunan (PBB) pada Kecamatan Ilir Timur II Kota Palembang. l ujuannya adalah untuk mengetahui apakah faktor tingkat pendapatan dan tingkat pendidikan mempengaruhi perilaku menunggak pembayaran Pajak Bumi dan Bangunan (PBB) di Kecamatan Ilir Timur II Kota Palembang.

Data yang digunakan yaitu data primer dan sekunder. Teknik pengumpulan data yang digunakan adalah wawancara. Kuisioner dan dokumentasi. Analisis yang digunakan analisis kuantitatif. Persamaan penelitian ini dengan penelitian pertama, kedua dan ketiga adalah sama-sama meneliti tentang Pajak Bumi dan Bangunan (PBB). Perbedaan penelitian ini dengan penelitian pertama adalah ingin mengetahui persepsi wajib pajak 
terhadap Pajak Bumi dan Bangunan, perbedaan dengan penelitian kedua adalah penelitian kedua membahas tentang evaluasi peiaksanaan penagihan aktif, perbedaan penelitian sekarang dengan penelitian ketiga adalah membahas factor tingkat pendapatan dan pendidikan berpengaruh terfiadap pembayaran $\mathrm{PBB}$, sedangkan penelitian sekarang membahas persepsi masyarakat terhadap kesadaran membayar pajak dan pemahaman peraturan Pajak Bumi dan Bangunan.

Sampai sekarang kesdaran masyarakat membayar pajak masih belum mencapai tingkat sebagaimana yang diharapkan. Umumnya masyarakat masih apriori karena masih merasa seperti upeti, memberatkan, ketidak mengertian masyarakat tentang pajak masih nampak di permukaan sosial. Namun masih ada upaya yang dapat dilakukan sehingga masyarakat sadar sepenuhnya untuk membayar pajak. Ketika masyarakat memiliki tingkat kesadaran maka membayar pajak akan dilakukan secara sukarela dan senang hati.

Kesadaran diartikan sebagai sikap atau perilaku untuk mengetahui atau mengerti, taat dan patuh kepada peraturan dan ketentuan yang berlaku.
Dilihat dari data yang diperoleh dari Kantor Kecamatan Tilamuta tingkat kesadaran masyarakat terhadap Pajak Bumi dan Bangunan masih berada dibawah jumlah yang ditetapkan. Oleh Karena itu dapat diperkirakan masyarakat belum semuanya sadar dan memahami hak dan kewajiban mereka sebagai wajib pajak. Dalam penelitian ini menggunakan beberapa acuan agar dapat dengan mudah menemukan hasil yang relevan.

PP No 71 Tahun 2010 lampiran ke II tentang Standar Akuntansi Pemerintahan, mendefinisikan pendapatan sebagai semua penerimaan Rekening Kas Umum Negara / Daerah yang menambah ekuitas dana lancar dalam periode tahun anggaran yang bersangkutan yang menjadi hak pemerintah, dan tidak perlu dibayar kembali. Peraturan Menteri Dalam Negeri No 13 Tahun 2006, mendefinisikan pendapatan sebagai hak pemerintah daerah yang diakui sebagai penambah nilai kekayaan bersih. Kedua definisi tersebut jelas terlihat bahwa pendapatan merupakan hak pemerintah yang menambah nilai ekuitas dana pemerintah. Kelompok pendapatan yang diterima oleh PPKD adalah sebagai berikut : 


\section{Pendapatan Asli Daerah (PAD)}

2. Dana Perimbangan (Pendapatan Transfer)

3. Lain-lain pendapatan Daerah yang Sah Pajak

Soemitro dalam Mardiasmo (2013:1) definisi pajak adalah iuran rakyat kepada kas Negara berdasarkan undang undang (yang dapat dipaksakan) dengan tiada mendapat jasa timbal (kontraprestasi) yang langsung dapat ditunjukkan dan yang digunakan untuk membayar pengeluaran umum.

\section{Pajak Bumi dan Bangunan (PBB)}

PBB menurut UU PBB adalah iuran yang dikenakan terhadap pemilik, pemegang kekuasaan, penyewa dan yang memperoleh manfaat dari bumi dan atau bangunan. Pengertian Bumi disini adalah termasuk permukaan bumi dan tubuh bumi yang ada dibawahnya. Bumi menunjuk pada permukaan bumi meliputi tanah dan perairan pedalaman serta laut wilayah Indonesia. Bangunan adalah konstruksi teknik yang ditanam atau diletakan secara tetap pada tanah dan atau perairan dan digunakan sebagai tempat tinggal atau tempat berusaha. Uraian di atas, dapat disimpulkan bahwa pengertian PBB adalah iuran yang dikenakan terhadap orang atau badan yangsecara nyata mempunyai hak, memiliki, menguasai dan memperoleh manfaat dari bumi dan bangunan. Berdasarkan UU No. 28/2009 tentang pajak daerah dan retribusi daerah yang baru, bahwa Selama ini PBB merupakan pajak pusat, namun hampir seluruh penerimaannya diserahkan kepada daerah.

\section{Objek PBB}

Pasal 2 Ayat (1) UU PBB, yang menjadi Objek PBB adalah bumi dan atau bangunan, permukaan bumi, tanah (perairan) dan tubuh bumi yang ada dibawahnya. Sedangkan bangunan yang juga dijadikan objek PBB adalah konstruksi teknik yang ditanam atau diletakan secara tetap pada tanah dan atau perairan. Selanjutnya penjelasan dari Pasal 1 Angka (2) UUPBB, menguraikan lebih lanjut mengenai pengertian bangunan yang menjadi objek PBB adalah : a. Jalan lingkungan yang terletak dalam suatu komplek suatu bangunan seperti hotel, pabrik, dan emplasemennya, dan lain-lain yang merupakan satu kesatuan dengan kompleks bangunan tersebut; b. Jalan TOL; c. Kolam renang; d. Pagar mewah; e. Tempat olahraga; f. Galangan kapal; g. Dermaga; h. Taman mewah; i. Tempat penampungan/kilang minyak, air dan 
gas; j. Pipa minyak; Objek PBB yang tidak dikenakan PBB pasal 3 UUPBB yaitu objek pajak yang : a. Digunakan sematasemata untuk melayani kepentingan umum yang tidak dimaksudkan untuk memperoleh keuntungan; b. Digunakan untuk kuburan, peninggalan purbakala, atau yang sejenis dengan itu; c. Merupakan hutan lindung, hutan suaka alam, hutanwisata, taman nasional, tanah pengembalaan yang dikuasai oleh desa, dan tanah negara yang belum dibebani oleh suatu hak; d. Digunakan oleh perwakilan diplomatik, konsultan berdasarkan asas perlakuan timbal balik; e. Digunakan oleh badan atau perwakilan organisasi internasional yang ditentukan oleh menteri keuangan; f. Objek pajak digunakan untuk penyelenggaraan pemerintahan; g. Besarnya Nilai Jual Objek Pajak Tidak Kena Pajak(NJOPTKP) ditetapkan paling besar Rp.12.000.000 (dua belas juta rupiah) untuk setiap Wajib pajak.

\section{Subjek PBB}

Subjek PBB menurut Pasal 4 UU PBB adalah orang atau badan yang secara nyata mempunyai suatu hak atas bumi, dan atau memperoleh manfaat atas bumi, dan atau memiliki, menguasai, dan atau memperoleh manfaat atas bangunan. Selanjutnya dapat dirinci, bahwa yang dimaksud subjek pajak sebagaimana dimaksudkan diatas adalah terdiri dari orang atau badan yang: a. Memiliki atau mempunyai hak atas bumi dan atau bangunan: 1) Memiliki atau mempunyai hak atas bumi (tanah) saja; 2) Memiliki atau mempunyai hak atas bangunan saja; dan 3) Memiliki atau mempunyai hak atas bumi (tanah danbangunan). b. Menguasai bumi dan atau bangunan: 1) Menguasai bumi (tanah) saja; 2) Menguasai bangunan saja; dan 3) Menguasai bumi (tanah) dan bangunan; c. Memperoleh manfaat atas bumi dan atau bangunan: 1) Memperoleh manfaat atas bumi (tanah) saja; 2) Memperoleh manfaat atas bangunan saja; dan 3) Memperoleh manfaat atas bumi (tanah) dan bangunan Berdasarkan rincian diatas, dapat disimpulkan bahwasubjek PBB adalah: a. Pemilik; b. Pemegang kekuasaan; c. Penyewa atau sebagainya.

\section{Dasar Hukum PBB}

a. UU No 12 Tahun 1985 tentang PBB b. PP No 46 Tahun 1985 tentang persentase NJKP pada PBB c. Kep. Menkeu No. 1002/KMK.04/1985 tentang Tata cara pendaftaran Objek Pajak PBB d. Kep. Menkeu No. 1003/KMK.04/1985 tentang penuntun klasifikasi dan besarnya NJOP sebagai dasar pengenaan 
PBB e. Kep. Menkeu No. 1006/KMK.04/1985 tentang tata cara penagihan PBB dan penunjukan pejabat yang berwenang mengeluarkan Surat Paksa f. Kep. Menkeu No. 1007/KMK.04/1985 tentang pelimpahan Wewenang penagihan PBB kepada Gubernur Kepala Daerah TK I dan/atau Bupati/Walikota Madya Kepala Daerah TK II g. Peraturan Pelaksana Lainnya h. UU No. 12 tahun 1994 Peraturan perpajakan tentang Ketentuan Umum dan Tata Cara Perpajakan telah beberapa kali mengalami perubahan, yang terakhir adalah Undang-Undang No. 16 Tahun 2009 tentang Ketentuan Umum dan Tata Cara Perpajakan. Perubahan-perubahan yang terjadi tercermin dari ketentuanketentuan yang mengatur sistem dan mekanisme pemungutan pajak. Sistem pemungutan pajak di Indonesia adalah sebagai berikut: 1. Pemungutan pajak merupakan perwujudan dari pengabdian, kewajiban, dan peran serta Wajib Pajak untuk secara langsung bersama-sama melaksanakan kewajiban perpajakan yang diperlukan untuk pembiayaan negara dan pembangunan nasional. 2 . Tanggung jawab dan kewajiban pelaksanaan pajak sebagai pencerminan kewajiban di bidang perpajakan berada pada Wajib Pajak sendiri. 3. Wajib Pajak diberi kepercayaan untuk dapat melaksanakan kegotongroyongan nasional melalui sistem menghitung, membayar, dan melaporkan sendiri pajak yang terutang.

\section{Kontribusi}

Kontribusi adalah sesuatu yang diberikan bersama-sama dengan pihak lain untuk tujuan biaya atau kerugian tertentu atau bersama. Sehingga kontribusi yang dimaksud dapat diartikan sebagai sumbangan yang diberikan oleh pendapatan Pajak Bumi dan Bangunan terhadap besarnya pendapatan daerah. Mahmudi (2010:145) menyatakan bahwa jika potensi penerimaan Pajak Bumi dan Bangunan semakin besar dan pemerintah daerah dapat mengoptimalkan sumber penerimaannya dengan meningkatkan target dan realisasi Pajak Bumi dan Bangunan yang berlandaskan potensi sesungguhnya, hal ini dapat meningkatkan total hasil penerimaan daerah. Sehingga akan mengurangi ketergantungan pemerintah daerah kepada pemerintah pusat.

\section{METODE PENELITIAN}

Dalam penelitian ini menggunakan metode kuantitatifdeskriptif dengan penelitian survei, yaitu yang mengambil sampel dan suatu 
populasi dan menggunakan kuesioner sebagai alat pengumpulan data yang pokok. Penelitian ini bertujuan untuk menjelaskan, meringkas berbagai kondisi, berbagai situasi/berbagai vaniabel yang timbul di masyarakat yang menjadi objek penelitian ini, berdasarkan apa yang terjadi kemudian mengangkat ke permukaan karakter/gambaran tentang kondisi, situasi, ataupun variabel tersebut.

\section{HASIL PENELITIAN}

Perpajakan merupakan salah satu komponen penting dalam perekonomian Indonesia, hal ini tercermin dalam APBN dengan jumlah pendapatan dari pajak hingga triliun pada APBN.Optimalnya pendapatan pajak untuk mendanai APBN merupakan wujud nyata kemandirian pendanaan pembangunan.Beragamnya peraturan dan perubahan yang ada di sektor pajak perlu disosialisasikan, sehingga Wajib Pajak memperoleh pemahaman dalam mengelola laporan keuangannya.

Selain itu, dunia usaha perlu memahami bahwa pajak memberikan kontribusi untuk pembangunan infrastruktur dan berbagai perangkat yang mendorong kemudahan melakukan usaha serta berbagai kebutuhan dalam membangun perusahaan dan memberikan kontribusi bagi pendapatan Negara. Pajak Bumi dan Bangunan (PBB) merupakan salah satu dari kebijakan reformasi perpajakan tahun 1985. Pajak Bumi dan Bangunan terdapat 5 jenis yang biasa disingkat menjadi P2 dan P3. PBB P2 sendiri adalah PBB sector pedesaan dan perkotaan sedangkan PBB P5 adalah PBB sektor perkebunan, perikanan dan pertambangan. Bumi dan bangunan merupakan dua obyek dari PBB, yaitu bumi yang dapat didefinisikan sebagai permukaan bumi yang berupa tanah dan perairan serta segala sesuatu yang dibawahnya, sedangkan bangunan adalah konstruksi teknik yang ditanamkan atau dilekatkan secara tetap pada tanah dan perairan di wilayah negara Indonesia.

Kontribusi, merupakan suatu tindakan untuk ikut serta bertindak aktif dengan mengoptimalkan kemampuan sesuai bidang dan kapasitas masingmasing yang dimaksudkan untuk memberi manfaat kepada masyarakat sekitar.Pajak Bumi dan Bangunan memberikan kontribusi dalam penerimaan Daerah melalui pembagian hasil dengan Pajak Pusat. 
Bagaimana persepsi masyarakat terhadap kewajiban membayar PBB di Kecamatan Tilamuta?

1. Pengetahuan masyarakat Kecamatan Tilamuta tentang PBB sudah cukup luas, yakni sebanyak 70\% responden. Namun, masih banyak PR untuk Dinas Pendapatan Daerah mengenai sosialisasi PBB kepada masyarakat, hal ini dikarenakan $60 \%$ responden menyatakan bahwa sosialisasi yang dilakukan pemerintah daerah kurang maksimal dan tidak merata

2. $80 \%$ responden mengaku telah menyiapkan alokasi dana untuk membayar PBB. Sebagai warga negara yang baik masyarakat harus membayar pajak tepat waktu sehingga memperlancar pembangunan dan fasilitas umum yang nantinya juga masyarakat yang menikmati hasilnya, oleh karena itu sebaiknya masyarakat sebaiknya menyiapkan dana alokasi untuk membayar PBB agar tidak "keteteran" ketika akan membayar PBB

3. Kesadaran masyarakat Kecamatan Tilamuta dalam membayar PBB sudah cukup tinggi, hal ini dikarenakan tingkat pendidikan yang mulai membaik di Kecamatan Tilamuta serta sosialisasi tentang PBB yang secara gencar oleh pemerintah bahkan oleh perguruan tinggi yang ada di wilayah ini. Namun, masih ada sebagian responden yang mengaku tidak ada waktu untuk membayar PBB sehingga mereka menunggu petugas pajak menagih ke rumah mereka

4. Masyarakat Kecamatan Tilamuta setuju bahwa Dinas Pendapatan Daerah sudah menyiapkan ruang pelayanan terpadu dengan telah membangun tempat pelayanan terpadu sejak tahun 2015. Hal ini dilihat dari jawaban responden sebanyak 80\%. diharapkan tempat pelayanan terpadu tersebut memudahkan wajib pajak dalam mengurus PBB.

5. Sosialisasi yang dilakukan oleh pemerintah daerah kurang maksimal. Hal ini dapat dilihat pada jumlah responden yang ragu atau kurang setuju bahwa sosialisasi tentang PBB telah dilakukan dengan baik sebanyak 60\%. Padahal sosialisasi tentang PBB menjadi kunci utama dan keberhasilan suatu daerah dalam menghadapi rendahnya kesadaran masyarakat dalam membayar PBB 
Faktor-faktor apa saja yang terkait dengan terbentuknya persepsi masyarakat terhadap kewajiban membayar PBB di Kecamatan Tilamuta Kabupaten Boalemo?

1. Tingkat Pendidikan.

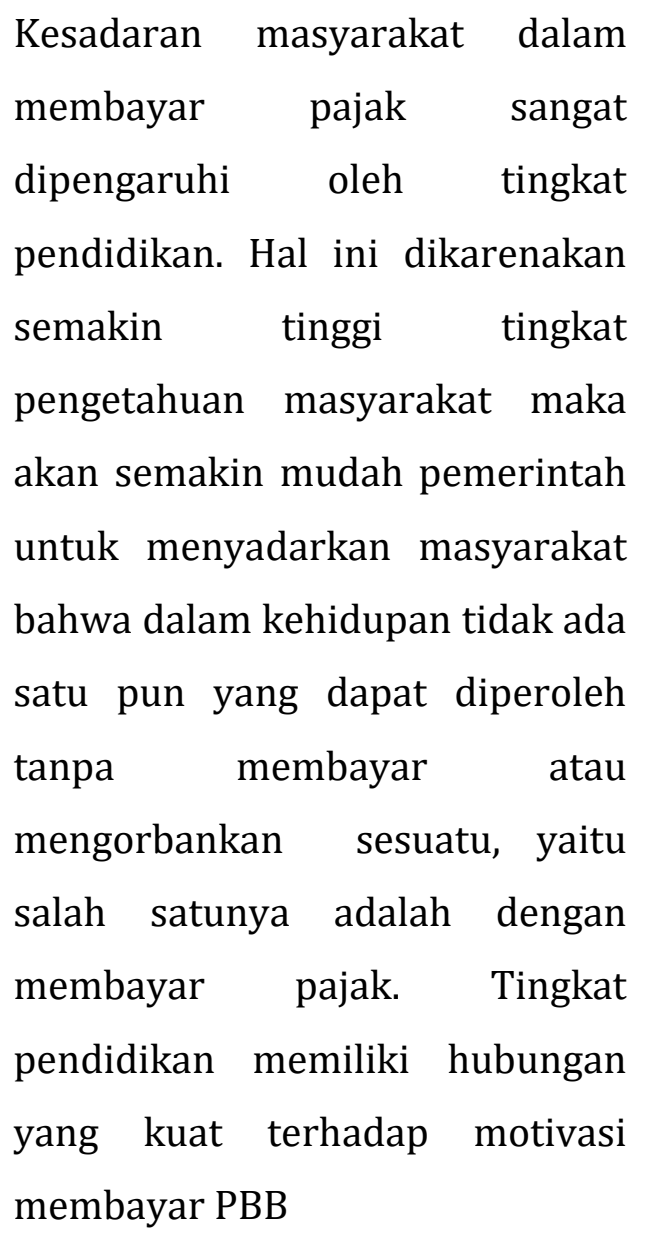

2. Pengetahuan masyarakat tentang Pajak.

Pengetahuan masyarakat tentang Pajak Bumi dan Bangunan meliputi peraturan mengenai PBB, fungsi dan mafaat dan PBB yang dibayarkan, tata cara dan tempat membayar PBB, mengetahui tanggal jatuh tempo, sanksi dan denda jika tidak membayar PBB tepat waktu, dan cara menghitung PBB.

3. Pelayanan Pajak Pelayanan

Adalah suatu kegiatan yang terjadi dalam interaksi langsung antara seseorang dengan orang lain atau mesin secara fisik, dan menyediakan kepuasan pelanggan. Disini penulis mendefinisikan pelayanan PBB menjadi 2 (dua) yaitu penyampaian SPPT, yang dimaksud adalah mekanisme penyerahat SPPT dan DPKA yang disalurkan kepada petugas di kantor kecamatan kemudian disalurkan kepada kantor desa sesuai dengan domisili wajib pajak, dan kantor desa SPPT diserahkan kepada Kepala dusun untuk diserahkan kepada wajib pajak. Selain itu tempat pembayaran yang nyaman dan cukup mudah di jangkau oleh wajib pajak yang ingin membayar juga merupakan bagian dan pelayanan. Dan wawancara informal yang dilakukan penulis kepada wajib pajak, menyimpulkan standart pelayanan saat membayar adalah 
pelayanan petugas yang cepat, tepat jumlah, dan ramah. Selain itu wajib pajak juga berharap penambahan fasilitas seperti bangku tambahan agar lebih nyaman saat mengantri.

4. Sosialisasi Undang-Undang tentang Pajak Bumi dan Bangunan.

Jika sosialisasi Undang-undang tersebut maksimal dijalankan maka dapat mempengaruhi persepsi masyarakat mengingat sekarang PBB yang dibayarkan akan dimanfaatkan untuk pembangunan di daerah wajib pajak tersebut seperti perbaikan jalan, pembangunan rumah sakit, dan pembangunan fasilitas umum.

\section{KESIMPULAN}

Berdasarkan hasil penelitian, analisis data, dan hasil kajian, penulis dapat menyimpulkan hal-hal sebagai berikut:

1. Sebagian besar responden sudah mengetahui tentang apa itu Pajak Bumi dan Bangunan, yaitu sebanyak 70\%. Responden yang mengaku mengetahui tersebut beralasan karena di tempat kerjanya sering membahas
PBB, pemberitaan dan kajian mengenai PBB sering muncul di media massa. Sebagian kecil responden yang mengaku sangat mengetahui PBB beralasan bahwa PBB dinilai sebagai sebuah keniscayaan, dimana dengan membayar PBB, masyarakat membantu pemerintah dalam hal pembangunan daerah. Dalam melakukan pembayaran PBB, seharusnya masyarakat mengetahui apa fungsi/ manfaat dan PBB tersebut, yaitu salah satunya adalah untuk pembangunan suatu daerah.

2. Kesadaran masyarakat Kecamatan Tilamuta dalam membayar PBB sudah cukup tinggi, hal ini dikarenakan tingkat pendidikan yang mulai membaik di Kecamatan Tilamuta serta sosialisasi tentang PBB yang secara gencar oleh pemerintah belakangan ini. Namun, masih ada sebagian responden yang mengaku tidak ada waktu untuk membayar PBB sehingga mereka menunggu petugas pajak menagih ke rumah mereka.

3. Sosialisasi yang dilakukan oleh pemerintah daerah sudah berjalan baik namun kurang maksimal. Hal ini dapat dilibat pada jumlah responden yang ragu atau kurang setuju bahwa sosialisasi tentang PBB telah 
dilakukan dengan baik sebanyak 60\%. Padahal sosialisasi tentang PBB menjadi kunci utama dan keberhasilan suatu daerah dalam menghadapi rendahnya kesadaran masyarakat alam membayar PBB.

4. Masyarakat Kecamatan Tilamuta setuju bahwa Dinas Pendapatan Daerah sudah menyiapkan ruang pelayanan terpadu dengan membangun tempat pelayanan terpadu sejak tahun 2015 akhir. Hal ini dilihat dan jawaban responden sebanyak 80\%. diharapkan tempat pelayanan terpadu tersebut memudahkan wajib pajak dalam mengurus $\mathrm{PBB}$.

Berdasarkan asumsi diatas, maka dapat disarankan sebagai berikut:

\section{Bagi Pemerintah}

a. Diperlukan sosialisasi tentang PBB secara periodik dan merata di 12 desa di Kecamatan Tilamuta guna meningkatkan kesadaran masyarakat untuk membayar PBB tepat waktu.

b. Memberikan ruang pendapat agar pemerintah daerah dapat menampung aspirasi, saran, serta kritik dari masyarakat guna mengevaluasi kinerja pelayanan pajak.

c. Diharapkan manajemen Pajak lebih transparan dan fokus dengan cara mengalokasikan anggaran yang bersumber dan penerimaan PBB untuk pembangunan infrastruktur yang lebih produktif dan dibutuhkan oleh masyarakat sehingga masyarakat dapat langsung menilai kinerja pemerintah dan mengontrol kinerja pemerintah.

\section{Bagi Masyarakat}

a. Masyarakat harus menjadikan PBB sebagai barometer terdepan dalam pembangunan daerah. Dengan demikian masyarakat tidak lagi banya sebagai objek pasif. Namun biasa menjadi aktor yang dapat berperan aktif di dalam menciptakan pemerintahan yang baik (Good Governance).

b. Masyarakat harus lebih peduli serta berperan aktif dalam mengontrol dan mengawasi kinerja pemerintah daerah sehingga pengelolaan PBB lebih efektif dan efisien.

Keterbatasan Penelitian Dalam melakukan penelitian, penulis memiliki 
beberapa keterbatasan. Keterbatasan pada penelitian ini adalah sebagai berikut:

1. Keterlibatan responden yang dirasakan jumlahnya masih belum dibandingkan dengan jumlah wajib pajak yang berada di Kecamatan Tilamuta. Hal ini dikarenakan adanya keterbatasan waktu, biaya, dan kemampuan yang tersedia.

2. Peluang terjadinya data yang bias yang dikarenakan oleh perbedaan responden dalam memberikan jawaban dengan strata sosial yang berbeda.

\section{Daftar Pustaka}

Arikunto, Suharsimi. 2005. Manajemen Penelitian. Jakarta : Rineka Cipta.

Dwiyanto Agus. 2011. Manajemen Pelayanan Publik Peduli, Inklusif, dan Kolaboratif. Yogyakarta : Gadjah Mada University Press

Rakhmat, Jalaludin. 2005. Psikologi Komunikasi, edisi revisi. Bandung : remaja Rosdakarya.

Sedarmayanti. 2017. Perencanaan dan Pembangunan Sumber Daya Manusia Untuk Meningkatkan Kinerja,
Produktivitas Kerja. Bandung : PT Rafika Aditama

Sugiyono. 2009. Metode Penelitian Pendekatan Kuantitatif, Kualitatif, dan R \& D. Bandung : Alfabeta.

Suryono, 2010. Teori dan Isi Pembangunan. Universitas Negeri Malang. UM Press

Suharman. 2005. Psikologi Kognitif. Surabaya : Srikandi.

Sutrisno, Lukman. 1995. Menuju Masyarakat Partisipatif. Yogyakarta : Kanisius.

Toha, Miftah. 1998. Perilaku Organisasi, Konsep Dasar dan Aplikasinya. Jakarta : Grafindo Persada.

Usman, Husaini. 2003. Metode Penelitian Sosial. Jakarta : Bumi Aksara.

Walgito, Bimo. 2004. Pengantar Psikologi Umum. Yogyakarta : ANDI.

Zubaedi, 2007. Wacana Pembangunan Akternatif. Ar-Ruzz Media. Jogyakarta.

Peraturan Perundang-undangan : Undang-undangRepublik Indonesia Nomor 12 Tahun 
1994 Tentang Pajak Bumi dan Bangunan.

Sumber Arsip :

Boalemo dalam Angka Tahun 2017

Buku Pedoman Fakultas Ilmu Sosial dan Ilmu Politik Universitas Ichsan Gorontalo Tahun 2015 